\title{
Antipsychotic medication therapy during the holy month of Ramadan: a literature review
}

\author{
Yousef Ahmed Alomi*, (iD General \\ Administration of Pharmaceutical Care, \\ Ministry of Health, Riyadh, SAUDI ARABIA. \\ Jude Alhowaidi, General Administration \\ of Pharmaceutical Care, Ministry of Health, \\ Riyadh, SAUDI ARABIA. \\ Raneem Alzeer, General Administration \\ of Pharmaceutical Care, Ministry of Health, \\ Riyadh, SAUDI ARABIA. \\ Ali Alhowaidi, General Administration of \\ Pharmaceutical Care, Ministry of Health, \\ Riyadh, SAUDI ARABIA. \\ Nora Alhowaidi, General Administration \\ of Pharmaceutical Care, Ministry of Health, \\ Riyadh, SAUDI ARABIA
}

\section{Correspondence:}

Yousef Ahmed Alomi, Bsc. Pharm, MSc Clin Pharm, BCPS, BCNSP, DiBA

The Past General Manager of General Administration of Pharmaceutical Care Head, Saudi Clinical Pharmacy Forum Head, Pharmacy R\&D Administration, Ministry of Health, P.O.BOX 100, Riyadh 11392, Riyadh SAUDI ARABIA

Phone no: +966504417712 E-mail: yalomi@gmail.com
Received: 20-12-2018;

Accepted: 19-2-2019

Copyright: (c) the author(s),publisher and licensee Pharmacology, Toxicology and Biomedical Reports. This is an open-access article distributed under the terms of the Creative Commons Attribution NonCommercial License, which permits unrestricted non-commercial use, distribution, and reproduction in any medium, provided the original work is properly cited.

This is an open access article distributed under the terms of the Creative Commons Attribution-NonCommercial-ShareAlike 4.0 License

Access this article online

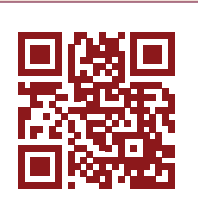

www.ptbreports.org

DOI:

10.5530/PTB.2019.5.14

\begin{abstract}
Objectives: To review the antipsychotic medication therapy during the holy month of Ramadan. Methods: In this study, we performed an extensive search of 50 databases through the Saudi Digital Library search engine. We included meta-analysis, randomized controlled studies and observational studies published in English language in May 2017. The search terms included Ramadan, fasting, medication, therapy, type of disease, and medication based on therapeutic class. The search on antipsychotic and anti-epileptic medication list and switch from regular days to Ramadan days included comparative safety, efficacy and cost of type of medication for each disease and national or international evidencebased guidelines including those switching short half-life to long half-life drugs. All nonoral dosage form of medication will be excluded in this study. All medications should be documented in the Ministry of Health drug formulary. Results: A total of 710 studies were shortlisted after an extensive search with specific terms. Of those, 104 studies were duplicate studies; therefore only 606 studies were included for further evaluation. The evaluation revealed that 27 studies discussed about the antipsychotic medications and Ramadan. Of these, only five were appropriate for further revision. According to our results, most of the studies were observational studies and a few have conducted experimental design studies. Three studies have a shared or similar study design (i.e., reports). Among all the reports analyzed in this study, most of them used study design. On the contrary, three studies mentioned the utilization of a descriptive approach; however, none of the studies mentioned the exact type of descriptive analysis conducted. One study was a clinical review and another study mentioned the applicability of a randomized controlled trial. Based on this, the authors suggested switching the antipsychotic and anti-epileptic medication from regular days to Ramadan days. Conclusion: There are no randomized clinical trials in the literature to validate the switching of medication from regular to Ramadan days. A list of antipsychotic medications that can be used to switch during Ramadan is highly warranted. Further studies to validate the medication used to treat psychiatric conditions during the holy month of Ramadan is recommended.
\end{abstract}

Key words: Antipsychotic, Medication, Therapy, Ramadan, Review.

\section{INTRODUCTION}

The holy month of Ramadan is the ninth month in the Hijri calendar in which Muslims fast intermittently and refrain from eating, drinking and other habits such as smoking. A Muslim in Ramadan fasts from sunrise till sunset each day for up to 29 to 30 days. The fasting hours during the day can change from 11 to $18 \mathrm{~h}$ according to the lunar calendar; therefore, it is forwarded by 10 days each year. ${ }^{1}$ The concept of fasting in this holy month is to understand and learn patience and self-control. ${ }^{2}$ It enables a Muslim to be connected on a spiritual level and be more conscious religiously. ${ }^{2}$

According to the estimation, Muslims comprise $24 \%$ of the population worldwide (1.8 billion). ${ }^{3}$ As the majority of this population fasts, there are physiological characteristics that differ in terms of age, weight, sex, diet and physical activity. ${ }^{4}$ The impact of partial fasting on the body depends on the daily fasting time that can affect biomarkers. Moreover, medications, smoking and diet can cause have an effect as well. ${ }^{5,6}$ In previous studies, it has been concluded that fasting during Ramadan has led to significant weight loss and energy consumption. ${ }^{7}$ In contrast, it was demonstrated that fasting in Ramadan leads to weight gain and an increase in the energy intake in another study. ${ }^{8}$ Therefore, there is no clear conclusion which determines the exact effect of Ramadan on body composition.

During Ramadan, Muslims consume approximately two meals per day. Suhoor, which is the predawn meal, in which Muslims have enough food and fluid intake to preserve their energy during the day as much as possible. The second meal, Iftar, is the evening meal in which a Muslim breaks the fast with dates. ${ }^{9}$ Meal planning and food consumption are critical for patients to adhere to in order to reschedule medication intake for chronic conditions between meals or during a meal. ${ }^{9}$ Taking oral formulations of a drug during fasting can contradict a fast. Patients have difficulty sustaining their dosage regimen by skipping doses during fasting. Consequently, specific strategies such as the use of long-acting formulations or twice daily dosing regimens for drugs given multiple times per day during other months, have been implemented to avoid breaking the fast. Furthermore, it has been shown that during Ramadan there is a better medication adherence by the patient than that of other months. ${ }^{5}$ The use of antipsychotic and antiepileptic drugs during Ramadan is strictly scheduled. ${ }^{10}$ 
The number of relapses of mood disturbances during Ramadan has been previously reported for bipolar patients. It has been demonstrated that the relapses for fasting patients were higher than that of nonfasting patients; this emphasizes the importance of following the medication regimen during Ramadan. ${ }^{11}$ However, the correlation between fasting and a manic or depressive episode of bipolar remains unclear. ${ }^{11}$ Another study determined the frequency of seizures during fasting. Previously it was assumed that fasting was considered as a treatment for epilepsy. ${ }^{12}$ The mechanism in which fasting can cause anti-epileptic effects remains under investigation. However, animal trials have supported this claim. ${ }^{12}$ Regardless as to whether fasting can have a positive outcome on mood or seizure frequency, the emphasis of patient adherence to medications during Ramadan should not be different from nonfasting days. Although physiological changes can occur differently during Ramadan days, antipsychotic and anti-epileptic medication levels and effects are being continuously studied. Therefore, in this study, we aimed to explore the review of fasting Ramadan and antipsychotic as well as anti-epileptic medications.

\section{METHODS}

In this study, we performed an extensive search on 50 databases through the Saudi Digital Library (SDL) search engine: Wiley Online Library, Web of Science, Springer Link, Taylor and Francis, Social Science Journal accessed via ProQuest, Science Journal accessed via ProQuest, Scopus, SciFinder, Science Direct, Sage Journal, Royal Society of Medicine, Royal Society of Chemistry, Psychology Journals accessed via ProQuest, Pharmaceutical News Index accessed via ProQuest, Patient Education accessed via MD Consult, Drug accessed via MD Consult, Oxford Journals accessed via Oxford University Press, Ovid Journals, Nursing and Allied Health Sources accessed via ProQuest, Nature Publisher Group, MEDLINE Index accessed via ProQuest, MEDLINE Complete accessed via EBSCO, Medical Evidence Matter accessed via ProQuest, IGI InfoSci Journals, Health Management accessed via ProQuest, Health and Medical Complete accessed via ProQuest, Global Health Database-CABI, Family Health accessed via ProQuest, Eric accessed via ProQuest and EBSCO, Emerald, DynaMed accessed via EBSCO, Directory of Open Access Journal (DOAJ), Current Content accessed via Web of Knowledge, Dentistry and Oral Science accessed via EBSCO, Clinical Key-Nursing, Clinical Key-Physician, CINAHL accessed via EBSCO, Central accessed via ProQuest, CBCA accessed via ProQuest, Canadian Science Publishing, Cambridge Journals accessed via Cambridge University, Britannica Academic, BMJ Journals, BMJ Clinical Evidence accessed via BMJ Best Practice, BMJ Best Practice, Biology Journals accessed via ProQuest, ACM Digital Library, Academic Search Ultimate accessed via EBSCO, Cochrane Library PubMed. In addition to Google Scholar searched a lone without SDL. We included meta-analysis, randomized controlled studies and observational studies in English language in May 2017. The search terms included Ramadan, fasting, medication, therapy, type of disease and medication based on therapeutic class. The antipsychotic and anti-epileptic medication list and switch from regular days to Ramadan days based on literature found the search, that's included comparative safety studies, efficacy studies and cost of type of medication for each disease studies and national or international evidence based guidelines of switching short half-life to long half-life. ${ }^{13-15}$ The list containing antipsychotic and anti-epileptic medication included drug name, general dosing and frequency of administration during regular and Ramadan days. All settings of patient care services such as inpatient, ambulatory care, or community services oral medication were included. All non-oral dosage form of medication were excluded from analysis. All medications should $\mathrm{MOH}$ drug formulary. The study location included Saudi Arabia as top the priority after Gulf or Middle Eastern countries; if this data was not found, then all countries were included in the analysis. If studies evidence not existed; the suggested came from author's experiences.

\section{RESULTS}

A total of 710 studies were obtained after an extensive search with specific terms. Of those, 104 were duplicate studies and 606 were included for further evaluation. The evaluation revealed that 92 studies discussed about medications related to diabetes mellitus and Ramadan, 27 studies discussed about the psychiatric medications and Ramadan, 27 studies investigated medications related to gastrointestinal disorders and Ramadan, 30 studies discussed about the use of antibiotics and Ramadan, 30 studies discussed about the cardiovascular medications and Ramadan, 15 studies discussed about medicines for asthma and rheumatoid arthritis and Ramadan and 402 studies discussed about other diseases and Ramadan. Of those 30 studies, only 5 were appropriate for further evaluation. The authors retrieved and summarized a total of 5 studies. Five countries (Iraq, Kuwait, Morocco, Pakistan and Turkey) have conducted a study relative to antipsychotic and anti-epileptic drugs.According to our results, most of the studies were observational studies and a few had experimental design in it. Three studies shared similar study design (reports). Reports were the most used method amongst the studies. On the contrary, three studies have mentioned the utilization of a descriptive approach; however, none of those mentioned the exact type of descriptive analysis conducted. Only one study resorted to clinical reviews. Moreover, only one study has mentioned the applicability of a randomized controlled trial.

There was one controlled study with one medication switch from three doses to two doses; the results showed there was a difference in the clinical outcomes and the concentration of medication. One study discussed about the drug level during fasting without any difference in the Ramadan days.

Three studies showed positive and conclusive results and two studies showed negative and unfavorable outcomes. In contrast, one study showed both negative and positive results. The positive outcomes favored the use of medication (e.g., carbamazepine and lithium) during Ramadan, with the focus on the drug's efficacy and safety. Some studies, however, failed to mention the drugs involved despite having positive outcomes.

However, the remaining two studies with negative results highlighted multiple reasons such as misuse of drugs that could lead to drug-food interactions and even progression of disease without any misleading changes to the required regimen during Ramadan. Moreover, one study showed a mix of outcomes. Missed doses were the ultimate issue; however, the study has mentioned an alternative to the problem that could benefit patients using the drug in Ramadan such as using a long-acting formulation of the drug to avoid missed doses.

In addition to our findings, the studies involved have shared advantages and disadvantages and a few of the studies were vague in terms of their assets and drawbacks. One of the advantages is that the information regarding the type of drug used, dose and frequency were gathered from evidence-based guidelines and researches and have provided the appropriate dose needed for each drug during fasting. Although the studies have obvious advantages, one study had a unique advantage. This study that was conducted in Iraq has shown the aftermath of fasting on glucose levels in addition to the results regarding drug used. Most of the studies have failed to mention the type of drug involved such as those conducted in Turkey. Another adverse outcome that was common amongst the studies was the small sample size that was chosen (Table 1). Based on the previous literature the authors suggested switching the antipsychiatry and anti-epileptic medication from regular days to Ramadan days (Table 2). 


\begin{tabular}{|c|c|c|c|c|c|c|c|}
\hline No & Authors & $\begin{array}{c}\text { Year of } \\
\text { publication }\end{array}$ & $\begin{array}{c}\text { No of } \\
\text { participant }\end{array}$ & $\begin{array}{c}\text { Study design } \\
\text { (RCT, Observations, } \\
\text { etc.) }\end{array}$ & Medications & Outcome results & Advantages \\
\hline 1 & Assad, $\mathrm{A}^{16}$ & 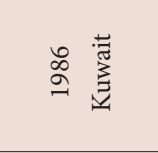 & 7 & 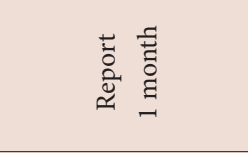 & $\begin{array}{c}\text { Multiple Psychiatric } \\
\text { Drugs }\end{array}$ & $\begin{array}{l}31 \text { psychiatric patients did not } \\
\text { comply for their drug regimen } \\
\text { during Ramadan while } 18 \text { did } \\
\text { comply. }\end{array}$ & \\
\hline 2 & $\begin{array}{l}\text { Aadil, N et } \\
\text { al. }^{17}\end{array}$ & 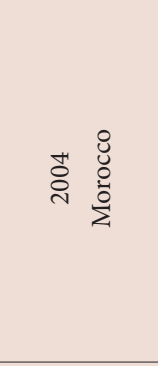 & 岁 & 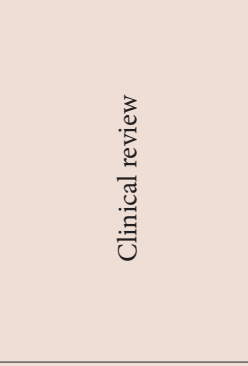 & $\begin{array}{l}\text { Carbamazepine, } \\
\text { Diazepam, Lithium }\end{array}$ & $\begin{array}{l}\text { Extensive misuse of prescribed } \\
\text { drugs during Ramadan may lead } \\
\text { to therapeutic failures and drug/ } \\
\text { food interactions }\end{array}$ & $\begin{array}{l}\text { Provide accurate and } \\
\text { standardized advice on } \\
\text { the appropriate use of } \\
\text { drugs during the holy } \\
\text { month of Ramadan. } \\
\text { incomplete descriptions } \\
\text { of the therapeutic } \\
\text { schemes observed } \\
\text { before and during } \\
\text { Ramadan, }\end{array}$ \\
\hline 3 & $\begin{array}{l}\text { Khattab, } \mathrm{E} \\
\text { et al. }^{18}\end{array}$ & 号 : & 아 & 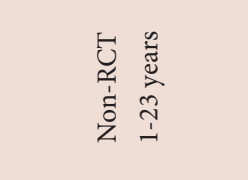 & Carbamazepine & $\begin{array}{l}\text { epileptic patients taking doses } \\
\text { of CBZ from three to two times } \\
\text { daily was safely fast Ramadan }\end{array}$ & $\begin{array}{l}\text { Only a few studies } \\
\text { have shown the effect } \\
\text { of Ramadan fasting on } \\
\text { serum glucose and this } \\
\text { study was one of them }\end{array}$ \\
\hline 4 & $\begin{array}{l}\text { Gomceli, } \\
\text { YB. et al. }{ }^{19}\end{array}$ & 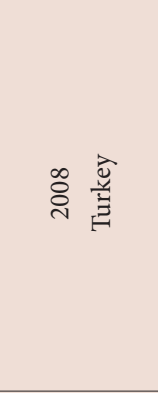 & $\stackrel{\Xi}{\exists}$ & 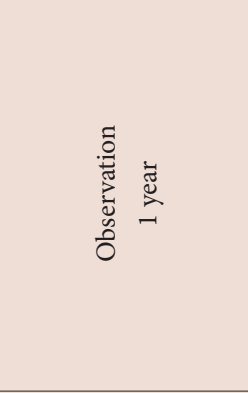 & NA & $\begin{array}{l}\text { Inpatients with epilepsy there } \\
\text { was an increase in seizure } \\
\text { frequency if they changed their } \\
\text { drug regimes. Change in drug } \\
\text { intake patterns, decrease in } \\
\text { sleep duration and/or sleep } \\
\text { fragmentation, emotional } \\
\text { stress and also tiredness, either } \\
\text { separately or all together, } \\
\text { influence the occurrence of } \\
\text { seizures during Ramadan fasting }\end{array}$ & $\begin{array}{l}\text { The drug involved } \\
\text { were not mentioned } \\
\text { throughout the study }\end{array}$ \\
\hline 5 & $\begin{array}{l}\text { Faroo, } \mathrm{S} \text { et } \\
\text { al. }^{20}\end{array}$ & 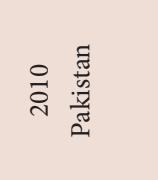 & ర్ & 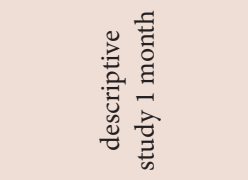 & Lithium & $\begin{array}{l}\text { it can be safely prescribed } \\
\text { without the undue fear of adverse } \\
\text { side effects during Ramadan }\end{array}$ & small sample size \\
\hline
\end{tabular}

\begin{tabular}{|c|c|c|c|c|c|c|c|}
\hline \multirow[t]{2}{*}{ No } & \multicolumn{3}{|c|}{ Drug therapy during Regular days $s^{21-25}$} & \multicolumn{3}{|c|}{ Drug therapy during Holy Ramadan } & \multirow[t]{2}{*}{ Registration*26 } \\
\hline & Regular Days & Doses/Day & $\begin{array}{c}\text { Frequency Per } \\
\text { day }\end{array}$ & Regular Days & Doses/Day & $\begin{array}{c}\text { Frequency Per } \\
\text { day }\end{array}$ & \\
\hline 1 & Amitriptyline & $50-150 \mathrm{mg}$ & $\begin{array}{l}\text { In } 1 \text { dose or } \\
\text { divided doses }\end{array}$ & Amitriptyline & $50-150 \mathrm{mg}$ & In 1 dose & RSFDA, MOHDF \\
\hline 2 & Amisulpride & $400-800 \mathrm{mg}$ & $\begin{array}{l}\text { Divided in } 2 \\
\text { divided doses }\end{array}$ & Amisulpride & $400-800 \mathrm{mg}$ & $\begin{array}{c}\text { Divided in } 2 \\
\text { divided doses }\end{array}$ & RSFDA , MOHDF \\
\hline 3 & Aripiprazol & $10-30 \mathrm{mg}$ & In 1 dose & Aripiprazol & $10-30 \mathrm{mg}$ & In 1 dose & RSFDA, MOHDF \\
\hline 4 & Citalopram & $20-40 \mathrm{mg}$ & In 1 dose & Citalopram & $20-40 \mathrm{mg}$ & In 1 dose & RSFDA, MOHDF \\
\hline 5 & Clobazam & $20-40 \mathrm{mg}$ & $\begin{array}{l}\text { In 1-2 divided } \\
\text { doses }\end{array}$ & Clobazam & $20-40 \mathrm{mg}$ & $\begin{array}{l}\text { In 1-2 divided } \\
\text { doses }\end{array}$ & RSFDA \\
\hline 6 & Clonazepan & $1.5-8 \mathrm{mg}$ & $\begin{array}{l}\text { In 2-3 divided } \\
\text { doses }\end{array}$ & $\begin{array}{l}\text { Clonazepan } \\
\text { Clobazam }\end{array}$ & $\begin{array}{l}1.5-8 \mathrm{mg} \\
20-40 \mathrm{mg}\end{array}$ & $\begin{array}{c}\text { In } 2 \text { divided doses } \\
\text { In } 1-2 \text { divided } \\
\text { doses }\end{array}$ & RSFDA, MOHDF \\
\hline 7 & Duloxetine & $60 \mathrm{mg}$ & In 1 dose & Duloxetine & $60 \mathrm{mg}$ & In 1 dose & RSFDA, MOHDF \\
\hline
\end{tabular}


Alomi, et al.: Antipsychotic Medication Therapy during the Holy Month of Ramadan

\begin{tabular}{|c|c|c|c|c|c|c|c|}
\hline 8 & Escitalopram & $10-20 \mathrm{mg}$ & In 1 dose & Escitalopram & $10-20 \mathrm{mg}$ & In 1 dose & RSFDA, MOHDF \\
\hline 9 & Fluoxetine Ecitalopram & $\begin{array}{c}20-60 \mathrm{mg} \\
\text { Maximum }\end{array}$ & In 1 dose & Fluoxetine Ecitalopram & $\begin{array}{c}20-60 \mathrm{mg} \\
\text { Maximum }\end{array}$ & In 1 dose & RSFDA, MOHDF \\
\hline 10 & Lacosamide & $200-400 \mathrm{mg}$ & $\begin{array}{c}\text { Divided in } 2 \\
\text { doses }\end{array}$ & Lacosamide & $200-400 \mathrm{mg}$ & Divided in 2 doses & RSFDA \\
\hline 11 & Lamotrigine & $100-500 \mathrm{mg}$ & $\begin{array}{c}\text { Divided in } 2 \\
\text { doses }\end{array}$ & Lamotrigine & $100-500 \mathrm{mg}$ & Divided in 2 doses & RSFDA, MOHDF \\
\hline 12 & Levetiracetam & $1000-3000 \mathrm{mg}$ & $\begin{array}{c}\text { Divided in } 2 \\
\text { doses }\end{array}$ & Levetiracetam & $1000-3000 \mathrm{mg}$ & Divided in 2 doses & RSFDA, MOHDF \\
\hline 13 & Olanzapine & $10-20 \mathrm{mg}$ & In 1 dose & Olanzapine & $10-20 \mathrm{mg}$ & In 1 dose & RSFDA, MOHDF \\
\hline 14 & Oxcarbazepine & $900-2400 \mathrm{mg}$ & $\begin{array}{l}\text { Divided in } 2 \\
\text { doses }\end{array}$ & Oxcarbazepine & $900-2400 \mathrm{mg}$ & Divided in 2 doses & RSFDA, MOHDF \\
\hline 15 & Paliperidone & $6-12 \mathrm{mg}$ & In 1 dose & Paliperidone & $6-12 \mathrm{mg}$ & In 1 dose & RSFDA, MOHDF \\
\hline 16 & Paroxetine & $10-20 \mathrm{mg}$ & In 1 dose & Paroxetine & $10-20 \mathrm{mg}$ & In 1 dose & RSFDA, MOHDF \\
\hline 17 & Pheynetion & $\begin{array}{c}300-400 \mathrm{mg} \\
\text { (Blood Level 10- } \\
20 \mathrm{mcg} / \mathrm{ml} \text { ) }\end{array}$ & $\begin{array}{l}\text { Divided in 1-3 } \\
\text { doses }\end{array}$ & Pheynetion & $\begin{array}{l}300-400 \mathrm{mg} \\
\text { (Blood Level 10- } \\
20 \mathrm{mcg} / \mathrm{ml} \text { ) }\end{array}$ & In 1 dose & RSFDA, MOHDF \\
\hline 18 & Pregabalin & $150-600 \mathrm{mg}$ & $\begin{array}{l}\text { Divided in 2-3 } \\
\text { doses }\end{array}$ & Pregabalin & $150-600 \mathrm{mg}$ & Divided in 2 doses & RSFDA, MOHDF \\
\hline 19 & Risperidone & $4-8 \mathrm{mg}$ & In 1 dose & Risperidone & $4-8 \mathrm{mg}$ & In 1 dose & RSFDA, MOHDF \\
\hline 20 & Sertraline & $25-100 \mathrm{mg}$ & In 1 dose & Sertraline & $25-100 \mathrm{mg}$ & In 1 dose & RSFDA, MOHDF \\
\hline 21 & Trandolapril & $1 \mathrm{mg}$ & In 1 dose & Trandolapril & $1 \mathrm{mg}$ & In 1 dose & RSFDA \\
\hline 22 & Trifluoperazine & $2-10 \mathrm{mg}$ & 2 times & Trifluoperazine & $2-10 \mathrm{mg}$ & 2 times & RSFDA, MOHDF \\
\hline 23 & Valporic Acid & $\begin{array}{c}1000-3000 \mathrm{mg} \\
(\text { Blood Level 40- } \\
100 \mathrm{mcg} / \mathrm{ml} \text { ) }\end{array}$ & $\begin{array}{l}\text { Divided in 2-3 } \\
\text { doses }\end{array}$ & Valporic Acid & $\begin{array}{c}1000-3000 \mathrm{mg} \\
\text { (Blood Level 40- } \\
100 \mathrm{mcg} / \mathrm{ml} \text { ) }\end{array}$ & Divided in 2doses & RSFDA, MOHDF \\
\hline 24 & Venlafaxine & $75 \mathrm{mg}$ & $\begin{array}{c}\text { Divided in 2-3 } \\
\text { doses }\end{array}$ & Venlafaxine ER & $37.5-75 \mathrm{mg}$ & In 1 dose & RSFDA, MOHDF \\
\hline 25 & Zonisamide & $100-600 \mathrm{mg}$ & In 1-2 dose & Zonisamide & $100-400 \mathrm{mg}$ & In $1-2$ dose & RSFDA \\
\hline 26 & Clomipramine & $25-100 \mathrm{mg}$ & In 1 dose & Clomipramine & $25-100 \mathrm{mg}$ & In 1 dose & RSFDA, MOHDF \\
\hline 27 & Fluvoxamine Maleate & $100-300 \mathrm{mg}$ & In 1 dose & Fluvoxamine Maleate & $100-300 \mathrm{mg}$ & In 1 dose & RSFDA, MOHDF \\
\hline 28 & Mirtazapine & $15-30 \mathrm{mg}$ & In 1 dose & Mirtazapine & $15-30 \mathrm{mg}$ & In 1 dose & RSFDA, MOHDF \\
\hline 29 & \multicolumn{7}{|c|}{${ }^{*}$ RSFDA: The Drug had been registered in Saudi Food and Drug Authority, MOHDF: The Drug is Ministry of Health Drug Formulary } \\
\hline
\end{tabular}

\section{DISCUSSION}

In the Middle East, the stigma of having a psychotic as well as the neurological disease remains an obstacle to date. For instance, a study that was conducted in Saudi Arabia showed that the level of understanding of the community towards epilepsy was limited. ${ }^{17}$ In Riyadh, Saudi Arabia, survey respondents were unaware of epilepsy. ${ }^{17}$ Moreover, a survey conducted in Jeddah, Saudi Arabia, have demonstrated a level of acceptance towards the disease but a massive misunderstanding of how the disease function. ${ }^{18}$ Public education and acceptance towards those disorders are vital to improving the field of research in terms of the medications used for those diseases, especially during Ramadan. Therefore, it is crucial to initiate multiple kinds of research surrounding this topic to enhance not only the public's awareness but to assess the appropriate usage of antipsychotic/antiepileptic in a fasting state.Moreover, the study methodology for the studies collected was mostly reported and only one of the studies conducted nonrandomized a clinical trial with limited number of medications. It is essential to enroll patients in experimental randomized clinical studies in order to have a significant meaning concerning the use of those medications in Ramadan and to reflect the study results to the general population and allow an area for improvement. In contrast, some of the studies have provided details regarding the drug, dose, frequency and use during Ramadan and others non mentioned. The authors suggested of drug list of antipsychotic and anti-epileptic and switch from regular days and Ramadan days. The limitations of the studies gathered were small sample sizes in the clinical trials, the use of reports predominantly, the limited number of studies available and the lack of mentioning the drugs used for specific studies.

\section{CONCLUSION}

In conclusion, this systematic review highlighted that the use of antipsychotic and antiepileptic medications during Ramadan has not been extensively evaluated and studied by current literature. The drawbacks were that the methodology chosen was not reliable nor sufficient for this type of field, although one study had performed non-randomized a clinical trial; however, the sample sizes were small with limited number of medications. Furthermore, the number of studies was minimal and some 
of the studies have not mentioned the drugs involved. We believe that there is a need for further examination through clinical trials in order to highlight the critical factors and switch therapy related to antipsychotic/ antiepileptic medications during Ramadan.

\section{ACKNOWLEDGEMENT}

None.

\section{CONFLICT OF INTEREST}

The authors declare that there are no conflicts of interest.

\section{ABBREVIATIONS}

MOH: Ministry of Health; KSA: Kingdom of Saudi Arabia; USA: United State of America; SDL: Saudi Digital Library.

\section{ORCID ID}

Yousef Ahmed Alomi iD https://orcid.org/0000-0003-1381-628X

\section{REFERENCES}

1. Abolaban $\mathrm{H}$, AlMoujahed A. Muslim patients in Ramadan: A review for primary care physicians. Avicenna J Med. 2017;7(3):81.

2. Chamsi-Pasha M, Chamsi-Pasha H. The cardiac patient in Ramadan. Avicenna J Med. 2016;6(2):33-8.

3. Pew Research Center. Muslims and Islam: Key findings in the U.S. and around the world. [cited 2019 Mar 11]. Available from: http://www.pewresearch.org/ fact-tank/2017/08/09/muslims-and-islam-key-findings-in-the-u-s-and-around-theworld/

4. Norouzy A, Salehi M, Philippou E, Arabi H, Shiva F, Mehrnoosh S, et al. Effect of fasting in Ramadan on body composition and nutritional intake: a prospective study. J Hum Nutr Diet. 2013;26(s1):97-104.

5. Khalife T, Pettit JMWB. Caring for Muslim Patients Who Fast During Ramadan Commentary. Am Fam Physician. 2006;86(9):1-2

6. Trepanowski JF, Bloomer RJ. The impact of religious fasting on human health. Nutr J. 2010;9(1):57.

7. AlHourani HM, Atoum MF. Body composition, nutrient intake and physical activity patterns in young women during Ramadan. Singapore Med J. 2007;48(10):906-10

8. Frost G, Pirani S. Meal frequency and nutritional intake during Ramadan: A pilot study. Hum Nutr Appl Nutr. 1987;41(1):47-50.

9. Grindrod K. Alsabbagh W. Managing medications during Ramadan fasting. Can Pharm J. 2017;150(3):146-9.

10. Alomi YA. Update 2018- Drug Therapy during Holy Month of Ramadan. Ministry of Health, Saudi Arabia. 2018.

11. Eddahby S, Kadri N, Moussaoui D. Fasting during Ramadan is associated with a higher recurrence rate in patients with bipolar disorder. World Psychiatry. 2014;13(1):97.

12. Bailey EE, Pfeifer $H H$, Thiele EA. The use of diet in the treatment of epilepsy. Epilepsy Behav. 2005;6(1):4-8.

13. Aadil N, Houti IE, Moussamih S. Drug intake during Ramadan. Br Med J. 2004; 329(7469):778-82.

14. Begum Y. GP guide to managing patients who wish to fast during Ramadan Prescriber. 2015:22(13-14):14-21.

15. Alomi YA. Update 2013- Drug Therapy during Holy Month of Ramadan. 2013.

16. Aslam M, Assad A. Drug regimens and fasting during Ramadan: A survey in Kuwait. Public Health. 1986;100(1):49-53.

17. Aadil N, Benyassine K, Benaji B, Benchekroun Y. Effect of Ramadan Fasting and Life Habits on the Antipyrine Test, Urine Volume and pH. Int J Pharm Sci Res. 2016:7(4):1422-9.

18. Khattab E, Psychiatry D, Mahmood IH, Abduljabbar ET, Ramadan D, Mahmood IH. Can Epileptic Patients on Carbamazepine Safely Fast Ramadan?. JIMA 2008:40(11):156-60

19. Gomceli YB, Kutlu G, Cavdar L, Inan LE. Does the seizure frequency increase in Ramadan?. Seizure. 2008;17(8):671-6.

20. Farooq S, Nazar Z, Akhtar J, Irfan M, Subhan F, Ahmed Z, et al. Effect of fasting during Ramadan on serum lithium level and mental state in bipolar affective disorder. Int Clin Psychopharmacol. 2010;25(6):323-7.

21. Bragazzi NL, BrikiW, Khabbache H, Rammouz I, Mnadla S, DemajT, et al. Ramadan fasting and infectious diseases: A systematic review. J Infect Dev Ctries. 2015;9(11):1186-94

22. Alomi YA, Alsolami N, Alqahtani N, Rahbini A. Depression Management Physician Order: New initiatives at the Mental Hospital of Ministry of Health in Saudi Arabia. J Pharm Pract Community Med. 2018;4(2):126-7.

23. AlomiYA, Alsolami N, Alqahtani N, Alqahtani D, Alqahtani S. Schizophrenia Treatment Physician Order: New Initiatives at the Mental Hospital of Ministry of Health in Saudi Arabia. Int J Pharm Heal Sci. 2018;1(1):1-5.

24. Alomi YA, Alsolami N, Alqahtani N, Rahbini A. Bipolar Disorder Management Physician Oder: New Initiatives at the Mental Hospital of Ministry of Health in Saudi Arabia. J Pharm Pract Community Med. 2018:4(2):124-5.

25. AhSee KW, et al. Royal Pharmaceutical Society. British National Formulary 76 British National Formulary. BMJ Group. 2019. Ministry of Health. Ministry of Health Formulary. Health Ministry of Health. 2012.

26. Ministry of Health. Ministry of Health Formulary. Ministry of Health. 2012. 